\title{
KEY RISK FACTORS AND IMPACT OF AFRICAN SWINE FEVER SPREADING ON PIG PRODUCTION IN SERBIA
}

\author{
Vladimir POLAČEK ${ }^{1 *}$, Jovan MIRČETA² ${ }^{2}$ Jasna PRODANOV-RADULOVIĆ ${ }^{1}$ \\ ${ }^{1}$ Scientific Veterinary Institute "Novi Sad”, Serbia; 2“"Vojvodina Šume” PE Enterprise, Novi Sad, Serbia
}

(Received 12 November, Accepted 30 November 2021)

\begin{abstract}
African swine fever (ASF) is a viral disease of domestic pigs and wild boars and currently represents a major threat to the swine industry worldwide. Disease control is impaired by a lack of an effective vaccine and currently, it is dependent on biosecurity measures in pig production, rapid diagnosis, and stamping out of infected herds. Consequently, this swine disease has considerable social-economic significance on national or even regional level. In 2019 for the first time ASF was detected in the domestic swine population (backyards) in the central region of Serbia. From then on, there have been continuous outbreaks of new cases in the population of domestic and wild boars. Considering domestic pig population, in the majority of cases, ASF was detected in small holdings and backyards. The biosecurity measures are not officially required by veterinary regulation and are only given in a form of recommendations. On the other hand, it is not always possible to implement biosecurity measures that are recognized today as essential for sustainable pig production in the old type of industrial pig facilities. Nowadays, in 2021, it became obvious that the domestic pig cycle, human activities involving pigs, or pig-derived meat products are the dominant driver of virus transmission. Additionally, human activities are frequently a risky connection between domestic pigs and wild boars both directly or indirectly. Traditional, culture-related aspects and facts that politicians failed to recognise ASF as a serious issue that causes great economical losses were found to be very important obstacles in disease control.
\end{abstract}

Keywords: African Swine Fever, domestic pig production, Serbia, wild boar

\section{INTRODUCTION}

African swine fever (ASF) is one of the most important viral diseases affecting Eurasian domestic pigs and wild boar population [1,2]. The causative agent is an enveloped DNA virus of genus Asfivirus within the Asfaviridae virus family [3] which is regarded as the only DNA virus that can be classified as an ARBO (arthropod borne) [4]. The virus originates from Eastern and Southern Africa, where it is maintained in an ancient sylvatic cycle in which African wild suids (predominantly warthogs) and argasid ticks (Ornithodoros moubata complex) constitute the natural hosts [4,5]. In the

\footnotetext{
*Corresponding author: e-mail: vlade@niv.ns.ac.rs
} 
past, ASF spread beyond the African region on three occasions [6,7]. Indeed, the ASF virus was endemic for nearly 40 years in Africa before it was introduced in Europe for the first time in 1957 and 1960 (Iberian Peninsula) and until 1995 sporadic outbreaks were detected in European countries [6,8]. Only in Italy, on the island Sardinia ASF (genotype I) has remained endemic from 1978 to this day [2,6,7].

In the last decade, once again ASF has reached an unprecedented geographical spread from Africa to Europe and Asia [5,9]. The starting point for the latest ASF incursion episode was in 2007 in Georgia, when the virus was introduced to the Eurasian continent $[5,10]$. After the first detection in Georgia, the ASF virus further spread to the Trans-Caucasian region, reaching the Russian Federation, Ukraine, Belarus [10-12] and then it very quickly spread to the regions of Eastern Europe and Baltic countries. Today, 14 years later, the epizootic has not been brought under control and the disease is progressively spreading each year to the territories of new countries [13,14]. At present, in the European continent, ASF is continuously spreading in central (Hungary, Slovakia) and especially the South-eastern countries (Romania, Bulgaria, Serbia, Greece) [15]. Moreover, in the summer of 2018, the disease arrived in another continent with the world's largest pig producer-China [16,17]. Recently, In Europe, the disease was confirmed in Germany: firstly in 2020 in the wild boar population located in the border area with Poland and in 2021 in domestic pig population [2,18]. Finally, according to the latest disease spreading update in 2021, it was officially confirmed that ASF was detected in the Dominican Republic. Currently, ASF affects more than 55 countries on 4 continents and is thus considered as one of the major threats to pig production worldwide [19].

In most of the European countries affected by ASF, the final eradication is still not in sight. Since 2007, the epidemiological situation has been developed into an ASF epidemic of unprecedented dimensions $[11,12,17]$. Despite its limited host range and non-existent zoonotic potential, the socioeconomic impact of this viral disease is extremely high [14]. Disease control is impaired by the lack of an effective vaccine and currently it is dependent on biosecurity measures in pig production, rapid diagnosis and stamping out of infected herds [20,21]. Indeed, ASF represents a global threat, given the associated considerable sanitary and socio-economic consequences [11,22,23].

A large number of virus serotypes are known, but to date only serotype 2 has been identified in Eurasia (serotype 1 is present only in Sardinia) [20,22]. The virus, of genotype 2 , is highly virulent with a case-fatality rate higher than $95 \%$ in domestic pigs and wild boars $[17,24,25]$. While in wild African suids ASF infection runs a subclinical or asymptomatic course, in domestic pigs and Eurasian wild boars this is acute and peracute severe hemorrhagic disease [5,11]. After infection, very high levels of the virus are present in the blood, in the secretions, and excretions, including urine, feces, saliva and this provides a major source for direct and/or indirect transmission [25,26]. Moreover, ingestion of infected material in feed or water can result in infection of pigs [5,11]. However, recent reports also suggest that moderately virulent ASF virus strains are circulating in Europe [25,26]. Regardless of serotype or ASF strain, early 
diagnosis of the first case within the region or country is imperative, after which the implementation of control measures urgently should follow $[8,9,27]$.

Today, after more than one decade of virus presence in Europe, it is well known that human activity can lead to transmission of ASF virus over short and long distances $[5,28,29]$. Indeed, nowadays human activities were recognized in several outbreaks as long/distance spreaders $[8,11,29]$. The best example for the ASF spreading mediated by human activity is the first case in Georgia in 2007, when the virus was successfully transported from Africa to Eurasia through infected waste from ships originating from Eastern Africa [10,15,30,31]. In this country, ASF infections were mainly detected on pig farms with low biosecurity and sporadically in the wild boar population [30]. On the contrary, in the western EU member countries, ASF dominantly survived in the wild boar population and it was not related to the outbreaks in domestic pigs [11,32]. Since the infection was dominantly detected in the wild boar population, a new, previously undescribed epidemiologic cycle focused on the wild boar population and its habitat as a virus reservoir became evident in Europe for the first time. It was named the wild boar-habitat cycle, and it was characterized by direct transmission between infected and susceptible wild boar and indirect transmission through carcasses in the habitat $[11,20]$. Soon after, the epidemiological analysis from the Estonian researchers showed that the presence of the virus in the wild boar-habitat cycle is the constant risk factor for the domestic pig population [26,32]. Generally, in the Eastern European countries the main population affected were wild boars, with sporadic cases in domestic pigs due to high infection pressure in farm surroundings and failures of biosecurity measures $[5,11,20,21]$. To date, only in three European countries, i.e., in Hungary, Belgium, and Czech Republic, ASF outbreaks were only been reported in wild boar population. [19]. At the same time, Czech Republic and Belgium are examples of the countries where ASF was successfully eradicated from wild boar population [13,28,30].

As mentioned above, analysis of the epidemiological situation in Europe, and in all EU members countries except Romania, shows that wild boar population is dominantly affected, accounting for more than $90 \%$ of ASF outbreaks $[19,32,33]$ On the contrary, in the ongoing epizootic in the neighboring country Romania, the epidemiology seems to follow dominantly the domestic cycle: the virus circulates among small pig farms, affecting commercial holdings and frequently spills over to wild boar population $[15,28,33]$. A similar domestic cycle has been present in Sardinia since 1978 where the disease is still endemic even today $[29,33]$. In the domestic cycle, the virus is transmitted among domestic pigs or from pig products to domestic pigs [15,21]. Generally, in the current disease spreading in the European continent each epidemiological cycle has been recognized as independent but intracycle disease transmission may occasionally occur especially due to anthropogenic factors [5,14]. Furthermore, anthropogenic factors and the virus spreading from the domestic cycle to the wild boar-habitat cycle have been evident in recent epidemics in South-East Europe [2,15]. Finally, nowadays the two main patterns of disease spreading in Europe are evident: slow local spread by direct contact and huge jumps of a few hundred kilometers. For both types of 
transmissions, humans are recognized as the main factors for disease introduction into uninfected regions [11,14,33]. Indeed, for the first case in China in 2018, the source of infection has been debated and anthropogenic long-distance transmission from Eastern Europe has been suggested [16,17].

In Southeastern Europe, the existence of a highly variable domestic pig farming system was previously reported [2,14,24]. Indeed, the main important difference comparing the EU member countries is related to the structure organisation of the domestic pig production sector. In this region there is a large number of smallholdings and in some countries semi-free and free-range domestic pig production is reported $[15,34,35]$. According to the EFSA report [15] in most of the countries, a significant percent of domestic pig population is managed under a backyard production system. However, besides the non-EU Western Balkan countries (Serbia, North Macedonia, Montenegro, Bosnia and Hercegovina, Albania), a similar situation can be found in the organization of the pig production sector in some EU member countries (for example Romania, Bulgaria). The pig production sector in Southeast Europe is quite different and cannot be transposed to intensive pig farming EU countries [15,17]. Also, in the first ASF infected country (Georgia), similar findings were recorded, where farming practices vary considerably from region to region $[15,24,30]$.

In the current epidemiological situation in Europe, a slow but constant local spread has been observed, dominantly in wild boar population and an endemic infection cycle has been established $[13,20,32]$. However, due to the different organizational structure in the pig production sector, the epidemiology ASF in Southeastern Europe seems to follow the domestic pig cycle $[4,15,36]$. In the current study, the specific risk factors affecting the spread of ASF in the domestic pig population in Serbia were considered. The aim of the research was to identify the key risk factors in further disease spreading and its potential impact on sustainable pig production.

\section{MATERIAL AND METHODS}

This paper presents and analyzes the official data provided by the Ministry of Agriculture, Forestry and Water Management of the Republic of Serbia (RS) regarding the number of domestic pigs and the structure of pig production. The collected data refer to the beginning of 2021. The data on the number of wild boars, categories, area and number of hunting grounds that were analyzed are official, updated data of the Ministry of Agriculture, Forestry and Water Management of RS - Forest Directorate, updated in March, 2021.

From the point of view of epidemiological analysis of ASF, this paper presents the official data about the ASF outbreaks in the population of domestic pigs and wild boars from National Animal Notification System - "VetUp" Latest Dispatch Date 9/4/2021, and Animal Diseases Notification System of EU - ADIS Total - outbreaks from 02/01/2021 until 23/10/2021: 15547 (Latest Dispatch Date by RS 15/4/2021) [37]. 
The data were analyzed using the ESRI ArcMap 10.8, ESRI ArcGIS Online, ESRI ArcGIS Pro 2.8 and Microsoft Excel 365.

\section{RESULTS}

\section{The number and structure of domestic pig production sector in Serbia}

According to the official categorization of pig holdings, five different pig production units types can be found in Serbia: commercial pig farm (industrial pig production, officially recognized with the high level of biosecurity); family farm of type A (farm with more than 10 animals and high level of biosecurity measures implemented); family farm of type B (farm with more than 10 animals but insufficient, low level of biosecurity); backyards, usually with few animals/pigs (less than 10) reared and kept mainly for self-consumption, with a low or total absence of biosecurity measures. Finally, free-range and semi-free-range pig keeping with any biosecurity. In this type of production, domestic pigs can come into direct contact with other domestic and wild animals.

Backyard pig production has the following main characteristics: production of meat for home consumption but also for local selling of few animals (as additional income). In this type of production, home slaughtering is widely practiced. Backyards are common practice in all villages in Serbia and this type of production is often characterized by swill feeding and almost any biosecurity measures. Most pigs are slaughtered at home in the beginning of winter. In spring, traditionally new animals (piglets) are bought again, sometimes at informal stock markets. Also, this type of breeding is characterized by the production of domestic traditional pork specialties.

Despite the fact that all the above-mentioned pig production units are very different from all aspects, according to the law, they are all classified as commercial holdings. This means that any domestic pig, regardless of which of the above-mentioned production units it originates from, can be sold, i.e. meat from all production units can enter the slaughter industry. The only precondition is that the pigs have been identified with official ear tags and a health certificate has been obtained (issued by an authorized veterinarian). Based on the official data Statistical Office of the RS, there were 2,983,102 pigs in 2020 and 1,260,970 were in Vojvodina [38].

The official data of the Veterinary Directorate differ from the above due to the fact that only ear-tagged pigs are recorded in the database (Figure 1). However, in percentage terms, over $50 \%$ of the domestic pig population is reared in production units with very low or no biosecurity measures (family farm type B, backyards, free-range).

Based on the basic data provided by the Ministry of Agriculture, Forestry and Water Management of the RS - Veterinary Directorate, the number of domestic pigs bred in Serbia depending on the type of farm is presented in Figure 1. 


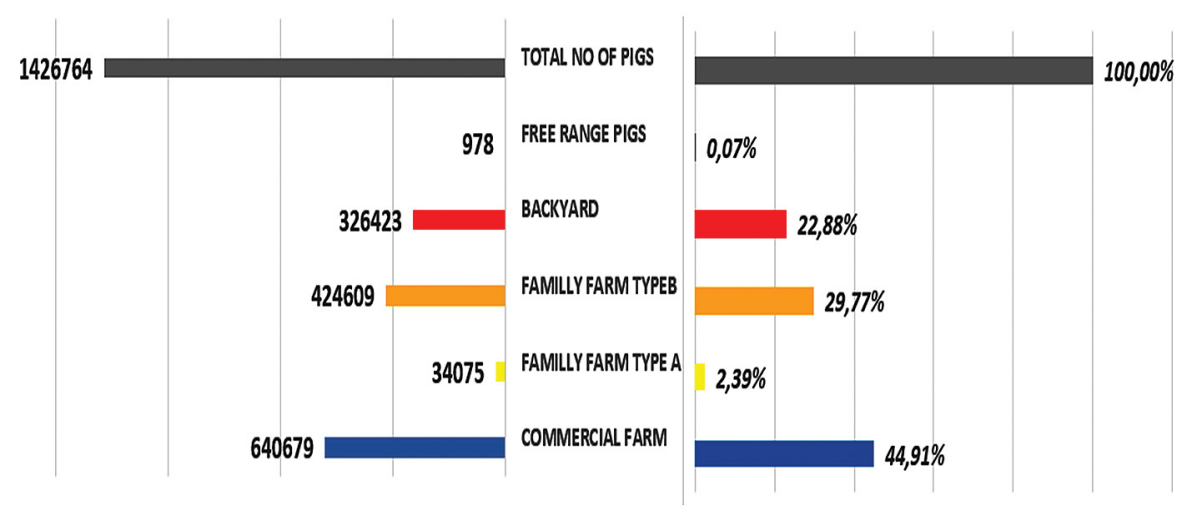

Figure 1. The number and percentage of domestic pig population by type of production (source Ministry of Agriculture, Forestry and Water Management of Republic of Serbia/ Veterinary Directorate, 2021 before ASF outbreak on large commercial pig farm in Zaječar municipality).

Also, based on the data shown on the map (Figure 2) it is quite obvious that industrial commercial production is localized in the North, and North-western part of the country. However, it is significant that on the western side of the Vojvodina Province
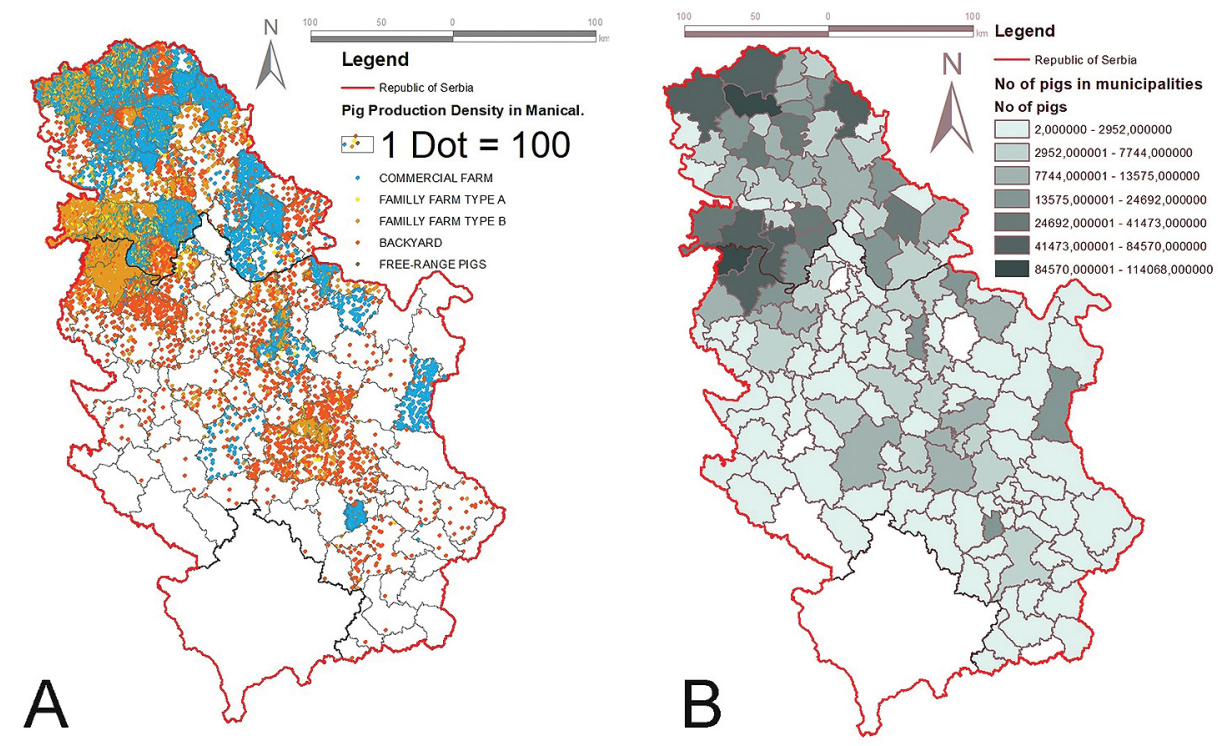

Figure 2. A Domestic pig population density by the type of production in Serbia before ASF outbreak on large commercial pig farm in Zaječar municipality on March 2021 blue dotscommercial farm, yellow dots family farm type A orange dots family farms type B, red dots-backyard, green dots- free range pigs; B. Number of domestic pig population within municipality before ASF outbreak on large commercial pig farm in Zaječar municipality on March 2021. 
region there are a large number of family farms that are classified as group B, i.e., a pig production system with a low level of biosecurity. According to the official data all risk factors recognized by the EFSA [16] as highly risk for ASF spreading are traditionally present in the South-east of the country: swill feeding, natural mating, contact with the population of wild boars (direct and/or indirect) as well as homeslaughtering of domestic pigs on smallholdings. In the North of the country, the epizootiological situation is somewhat better, primarily sporadic cases of swill-feeding, as well as a lower frequency of direct contact with wild boar population. However, the home-slaughtering of domestic pigs in smallholdings is present as a cultural and sociological phenomenon, as well as the practice of natural mating, precisely in the region with the highest density of domestic pig population (Srem and Mačva District).

\section{Characteristics of the wild boar population in Serbia}

According to the official data in the RS, there is $75,679.16 \mathrm{~km}$ of hunting grounds, out of which 82,612 ha are fenced hunting grounds. In the country in total 82,000 hunters and 1,200 hunting professionals (game wardens) are registered. The wild boar population is estimated to be about 25,606 individuals, and hunting bag is 11,179 hunted wild boars in the last hunting year (2020). Generally, the preventing measures in hunting grounds include continuous monitoring of the wild boar population health status, field search for carcasses of dead wild boars, sampling of hunted and dead wild boars, restriction/prohibition of additional feeding, ban of swill feeding, prohibition of entry into the hunting ground of pig/wild boar meat and non-heat-treated meat products without product declaration, population reduction, etc. Until the detection of the first case in the wild boar population, preventative measures were different in open and fenced hunting grounds, especially in the implementation of measures of population reduction and additional feeding. At the beginning of 2020, ASF was detected in wild boars in the East of the country, close to the country's borders with Bulgaria and Romania. Since then, numerous outbreaks in wild boars have been reported in the South-eastern part of Serbia (Figure 3).

In Serbia, there are nine enclosed hunting grounds or parts of the hunting grounds with a controlled population of wild boars located on the territory of Vojvodina Province. Despite of newly implemented biosecurity protocols for hunters, in 2021 the ASF was detected in the wild boar population located in an enclosed hunting ground (Vršačke planine) in the neighbouring area with Romania. In open hunting grounds, there is a possibility of direct and indirect contact of wild boars with the population of free-range domestic pigs. Especially in the East of the country, there are numerous smallholdings, non-fenced backyards where domestic pigs roam freely in the woods during the day in search for food. 


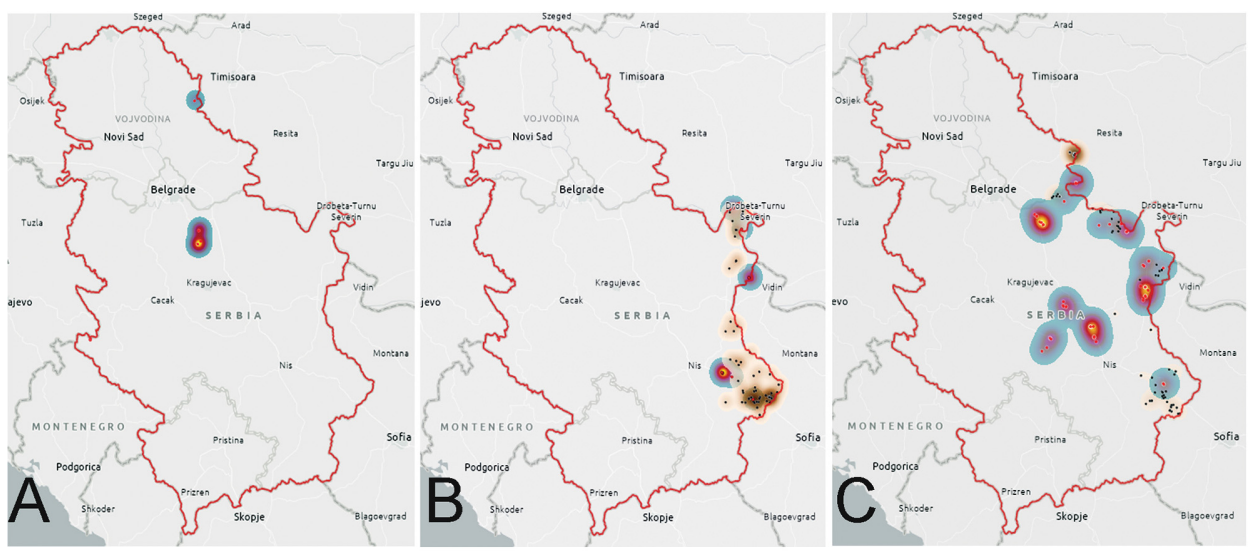

Figure 3. A ASF cases in 2019 in domestic pig population; B ASF cases in 2020 in domestic pig population (yellow/red/blue color sheme) and in wild boar population (brown color); C ASF cases in 2021 (until August $27^{\text {th }}$ in domestic pig population (yellow/red/blue color sheme) and in wild boar population (brown color).

\section{Epizootiological situation of ASF in Serbia (2019-2021)}

African swine fever was first recorded in Serbia in July 2019, about 50 km (Southeast) from Belgrade, in the municipalities of Mladenovac (villages of Velika Krsna and Rabrovac) and the municipality of Smederevska Palanka (village of Kusadak) [34]. A case of an outbreak of the ASF in municipality of Zitiste in the settlement of Srpski Itebej, on the border with Romania, was also identified later in the same year (Figure 3A.) In all the above-mentioned cases, in addition to stamping out of all pigs in the backyards, preventive depopulation of domestic pigs in contact backyards was performed, as well as thorough disinfection. Backyard farm owners got 100\% compensation for direct damage caused by destroying pigs, regardless of their pig breeding methods or potential ways of spreading ASF, according current market prices.

At the beginning of 2020, new cases of ASF outbreaks were registered and localized in the South-East of the country, mostly in the wild boar population. The same happened at the end of 2020 (Figure 3B.).

At the beginning of 2021, an outbreak was confirmed in the municipality of Zajecar, in the village of Veliki Izvor. Very soon after that, the ASF virus was confirmed for the first time on a large commercial farm, and over 18,000 domestic pigs were euthanized as part of control measures [35]. Afterwards ASF is spreading to smallholdings in different localities in the country, as well as in the wild boar population (Figure 3C.) The number of ASF cases in domestic and wild boar population in the period 20192021 is shown in Table 1. 
Table 1. Number of cases in domestic pigs and wild boars from 2019 to 2021 in Serbia

\begin{tabular}{ccc}
\hline Year & $\begin{array}{c}\mathbf{N}^{\circ} \text { ASF cases in the domestic pig } \\
\text { population }\end{array}$ & $\begin{array}{c}\mathbf{N}^{\circ} \text { ASF cases in the wild boar } \\
\text { population }\end{array}$ \\
\hline $2019^{*}$ & 15 & - \\
$2020^{*}$ & 15 & 71 \\
$2021^{* *}$ & 33 & 71 \\
\hline
\end{tabular}

* Source- Serbian National Animal Diseases Notification System (VetUp, Latest Dispatch Date 9/4/2021

** Source ADIS Animal Diseases Notification System of EU -Total outbreaks from 02/01/2021 until 23/10/2021:

15547 (Latest Dispatch Date by Republic of Serbia 15/4/2021).

In the Eastern region, near the border with Romania and Bulgaria, in the area with a total of 10 settlements (Dimitrovgrad, Donji Milanovac, Velik Izvor, Pirot, Prisjan, Vlasi, Poganovo, Goštuša, Rasnica, Kamnik), there were repeated cases of ASF in the wild boar population from 2020 to 2021 in the same or increased numbers with a tendency of enzootic occurrence (Figure 4).

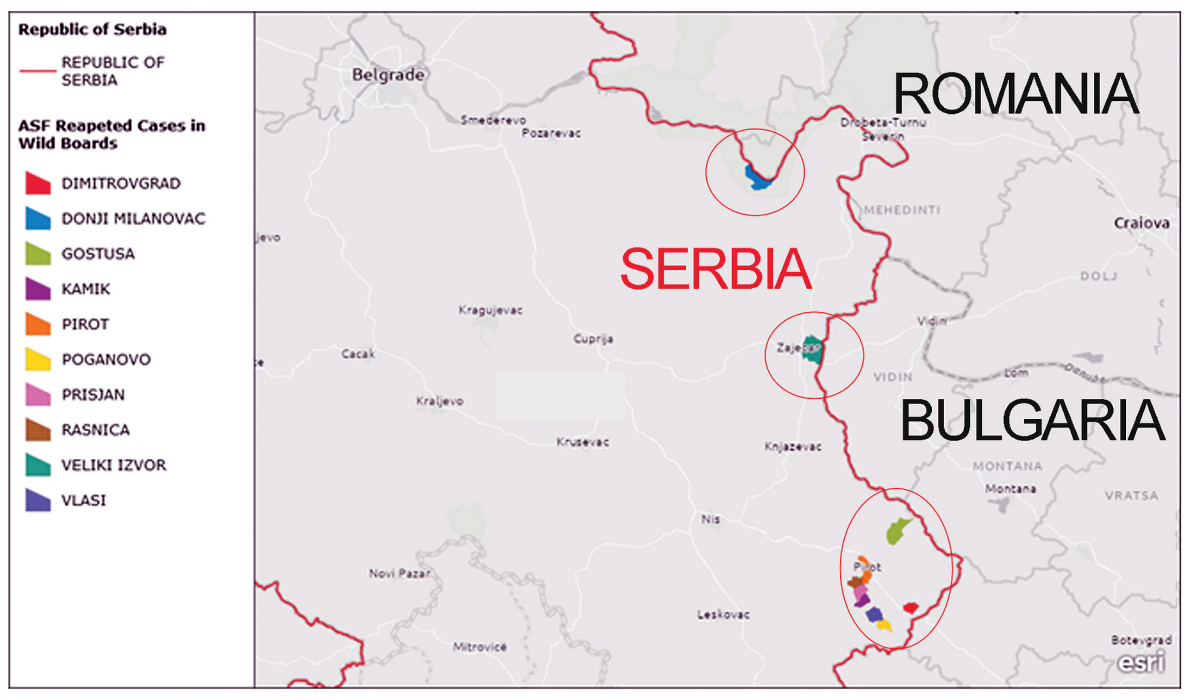

Figure 4. Repeated ASF cases in wild boar population in 2020 and 2021 (until August 27 $7^{\text {th }}$ ).

\section{Activities and measures taken in order to control and prevent ASF spreading in Serbia between 2019 and 2021}

Ever since the last quarter of 2019, active surveillance of ASF, together with surveillance on classical swine fever (CSF), has been carried out in Serbia. According to the plans for this surveillance, during 2021, the definition of suspected ASF case is every dead breeding animal (sow, boar) as well as abortions. Namely, the reporting of suspicion to ASF also means a ban on trade until the end of the diagnostic procedure, 
which leads to a ban on the trade of fatteners to slaughterhouses. Additionally, active surveillance of slaughterhouses in Serbia began in the last quarter of 2021. The most important measure that has been implemented in the RS according to the valid legislation between 2019 and 2021 is euthanasia of all pigs on farms with ASF confirmed case, disposal on the site which the local government marks as appropriate, disinfection and 100\% compensation for euthanized animals to owners. During 2019 and 2020, as a part of these measures, preventive depopulation of animals in contact farms were performed, but this measure was not applied during 2021. In addition to these measures, repopulation of animals was carried out 40 days after the last reported case and final disinfection. In the period between 2019 and 2021, logistics in terms of providing the most important resources in combating ASF, was the responsibility of the local government, which proved to be extremely impractical and inefficient. When it comes to ASF in wild boars, only in the case of outbreaks in the hunting grounds managed by state-owned companies, people were organized to search for the carcasses and remove them. They were able to provide sufficient financial resources necessary for the implementation of the measures in hunting grounds. In the case when ASF occurred in the hunting grounds managed by hunting associations, which are citizens' associations, there were no legal mechanisms for members of the association to be involved in finding and removing wild boar carcasses on hunting grounds.

The average value of compensation of one sow/boar in 2019 and 2020 was around 350 euros $(€)$, price of the disinfection was $0.17 € / \mathrm{m}^{2}$, euthanasia of a pig around $8.5 €$, and disposal in a rendering plant around $0.14 € / \mathrm{kg}$. The funds for the refund in the amount of 100\% were provided from the budget of the RS. For the sake of illustration, the costs of the ASF control measures in one farm with 5 fatteners, which are bred on a $2000 \mathrm{~m}^{2}$ large yard, according to the current market prices, the costs of euthanasia, disposal, disinfection of the farm costs at least 1,000 $€$. Another thing that needs to be added to this cost is the cost of manual labor, mechanization, fuel and other indirect costs. Similar to the previous calculation, if these measures are to be implemented on the territory of the entire village, which has 1,000 pigs that are raised in 200 households, the costs of ASF control measure are at least 200,000 €. If these measures need to be applied only on a 3.5-hectare farm where 18,000 pigs are bred, the cost of ASF control measures for the RS will be at least 2.3 million $€$.

\section{DISCUSSION}

Since 2019, most of the ASF outbreaks in Serbia have been detected in the domestic pig population in backyards and smallholdings. This is directly related to a low level of biosecurity in this type of production but also to other inherent sociological and cultural features (home slaughtering, swill feeding, natural mating). In Serbia, swillfeeding is forbidden by law. However, it is still practiced in rural areas and villages. Home slaughtering is allowed in all types of small holdings and is usually related for family meat consumption. Certainly, this practice could be an important cause 
for ASF spreading since all types of production units are recognized as commercial. Generally, in the EU, home slaughtering is recognized as a feature of non-professional pig production, which constrains ASF control [33,36,39].

In Eastern Europe, the outbreaks on pig farms have primarily been reported in areas where the virus is circulating in the wild boar population $[15,22,23]$. The outbreaks in domestic pigs are correlated with wild boars, indicating a link between the risk of ASF in domestic pigs and the level of contamination of the external environment $[20,21,40]$. However, the exact route of virus transmission can seldom be determined, and introductions into backyard and commercial pig farms are often attributed to indirect transmission mediated via humans [22,30,41]. According to the experience from the Baltic region, contamination with wild boar carcasses can frequently keep the virus alive in the local area around villages or pig farms [25-27]. On the other hand, inadequate or low level of biosecurity in small holdings and backyards is often mentioned $[21,24,25]$ as a potential risk factor that could play a role in ASF spreading in the domestic pig population [41,42]. Considering the infected territories in Southeast Europe, swill feeding, the presence of free-ranging pigs and home slaughtering, presence of a substantial number of smallholders were found as significant indicators for ASF spreading in the domestic pig production sector [24,30,41].

A high percentage of smallholders (52.72\%) in Serbia is recognized as an important risk factor for disease spreading due to a low level or non-existent biosecurity measures. In this group, we can include several production unit types: family farm type B, backyards, and free-range. Indeed, besides backyard pig production in some parts of the country, free-range domestic pig is a traditional husbandry practice in which pigs are raised in an extensive production system (woods, close to river banks) where the contact between domestic pigs originating from different owners and the contact with wild boars is facilitated. According to Bellini et al. [36], the presence of free-range pigs is an important element that has contributed to the spread and maintenance (persistence) of the ASF virus in different populations $[21,36]$. Another important factor is national identification and movement control system of the domestic pig population which is in Serbia just partially in place [15]. There is a high percentage of smallholdings which are a risk factor due to the lack of biosecurity and low traceability of pig movements to and from this type of farms [15,34,35]. Poverty is also well recognized as a cause of ASF spread [25]. Since the majority of pig farms are smallholders, it is believed that pig meat is mainly for local consumption. The likelihood of ASF spread is very high due to the structure of the domestic pig sector, the presence of wild boars but also social and cultural factors.

Serbia is a western Balkan country with a highly variable pig farming system characterized by a domination of traditional smallholdings, and backyard pig production $[15,34]$. This is an unprofessional, highly heterogeneous sector, characterized by a large number of smallholdings with few animals, low inputs, outdated technology and poor biosecurity. Pig production is spread heterogeneously throughout the country, with the lowest density in the Southeastern parts of the country and the highest 
densities found in north and North West parts (Figure $2 \mathrm{a}, \mathrm{b}$ ). Quite a large number of commercial, industrial pig farms is located in the east along the borders with Romania and in the North, North-west along the borders with Hungary and Croatia. Husbandry systems across the country vary in terms of the type of production system and final products: fatteners, piglets, fresh meat, different pork products (sausages, ham, bacon). Traditional farming methods in Serbia represent a cultural identity. According to the working document DS SANTE, which is a strategic approach to the management of ASF in the EU member states, it is recommended to classify pig farms in three categories: non-commercial, commercial and outdoor farms [21,42]. According to Bellini et al. [36] this classification takes into account the very important commercial attitude of the holdings rather than size of the farm, the number the animals in the holdings or type of the establishment. Considering the limited number of studies available on small holdings and backyard settings, Southeast Europe could be interesting from the epidemiological point of view for the EU countries [15]. In addition, backyards are not common or permitted in some EU countries or not present [42-44]. However, commercial pig production has various meanings in Serbia at the moment. Anyone who carries out the official animal ear-tagging in accordance with the law can obtain the necessary veterinary health certificate and sell pigs on the market all around the country. However, real industrial production implies commercial production from farrow-to-finish or just farrow-to-piglets production. Unofficially, we can distinguish two types of pig industrial holdings: the new one, built in the last 10 to 15 years and the older one, which in the past was owned by the state ("socialist model of governance"). In the 1990s, swine farms were privatized but new owners did not invest in biosecurity. Indeed, today we have a large pig production system, with a capacity from up to 2,000 sows but with an old type of production system. It is not possible to implement some of the biosecurity measures that we know today that are essential for sustainable pig production without major investments by the owners. Compared to small holdings, industrial farms have close frequent contacts with other premises. Despite having adopted some biosecurity measures in everyday practice, they still have a high risk of becoming infected. Timely and systematic analysis of morbidity and mortality in different categories, detecting all cases of abortions in sows can help in the early detection of ASF on an intensive swine farming unit. Biosecurity measures are not officially required by the law in Serbia and are only given in a form of general recommendations [35]. However, in the latest Government Instruction for ASF (Official Gazette of the RS, No. 40/14), it is said that commercial and family farms need to have officially written and implemented biosecurity plans for their own production.

In Serbia, rearing pigs in backyards is common traditional practice in villages, and quite often represents an important meat source for the entire family. Traditionally all backyards' farmers slaughter their pigs in their premises, mostly around Christmas. Home-slaughtered domestic pigs are usually intended for home consumption, but the meat can be also shared to relatives, friends or even sold to middlemen. It is well 
known that ASF virus can survive for long periods of time in pork and pork products, which increases the risk of ASF spread to ASF-free areas [11,14,21]. In the eastern parts of the country and the central region, most farmers feed their pigs with maize, rarely with complete feed mixtures and often supplement the diet of their animals with kitchen waste, originating from their own household but also from the local restaurants, hospitals or schools. Swill feeding is widespread, although it is forbidden by the law and clearly identified as a major risk for ASF transmission [34,35]. Another very important biosecurity issue in small holdings refers to the breeding practice in villages - the tradition of bringing boars in the yard for natural mating. This is a widespread practice, where several backyard owners provide a domestic boar for one community (usually for several villages in one municipality). This is especially common in the east and south part of the country, where it is quite rare to find the farmers who perform artificial insemination, with semen originating from controlled insemination centers.

Considering potential interactions of domestic backyard pigs with wild boars, in the East and South of the country, many farmers report wild boars close to their backyards. Also, a significant percentage of people in the villages are hunters. Generally, hygiene and disinfection are one of the most important measures in preventing ASF transmission, and the farmers that hunt wild boars have the key role [35,36,39]. A similar situation is reported in Sardinia as the only area where ASF has been detected in the free porcine populations: domestic pigs, wild boars and free-range pigs [29,33]. ASF virus has remained in Sardinia for more than 40 years and the island remains categorized as one with the highest risk areas in the EU, with consequent severe trade restrictions [22,39].

Undoubtedly, the existing backyard production system in Serbia directly endangers the survival of industrial farm pig production. This is exactly what the countries that are facing a decade-long fight against the ASF virus report [24,41]. It is clearly recognized that spreading and persistence of ASF in the Georgian and Caucasian region was mainly associated with backyard/small holding production and the movement and trade of infected pork products $[10,12,42]$. Although pig production is mostly industrialized in the north (Vojvodina Province), backyard pig production is still very popular in Serbia, probably because of specific social and cultural factors. Indeed, human activities and demography factors are recognized as the target points for virus transmission in the domestic pig population $[15,43]$. The role of wild boars in domestic pig infections is quite clear in some districts in the south-east country region. In Borski and Zajecarski District, there was a link between identified wild boar cases and domestic pig outbreaks, especially in 2020 .

Nowadays it is clear that ASF causes tremendous losses in the industrial pig sector and it also strongly affects livelihood of smallholdings in rural areas. However, small-scale farming is common in many countries, especially in rural areas of the Balkan region, representing a significant part of agricultural practices and tradition, and often serves as a source of meat supply and additional family income $[15,22,41]$. The experiences 
from other European countries suggest that any delay in ASF detection in previously ASF-free areas and consequent delay in the implementation of control measures increases the likelihood of disease spreading [12,16,41]. A passive surveillance system is crucial for early ASF detection $[4,13,15]$. However, analyses of domestic pig outbreaks in the current epizootic in Europe revealed that the contagiousness of ASF is comparatively low and that under field conditions, ASFV transmission between animals is considered to be slow. Long-distance jumps are most probably the result of human activities (anthropogenic factors), e.g., the transport of contaminated meat or meat products that are basically waste or kitchen leftovers. These examples show that due to anthropogenic factors, ASF has a huge capacity for transboundary and transcontinental spread $[6,8,14,17]$.

The ASF spreading in Romania during 2018 has highlighted a ASF spreading pattern focused on domestic pig holdings of all sizes, with few outbreaks reported in wild boars $[24,41]$. The situation in Romania cannot be directly transposed to other EU countries, but human activity was identified as the main risk factor for the spread of ASF. Romania is faced with a different type of epizootic and a majority of cases has been reported in backyard domestic population $[8,15]$. The reason for this is a failure to implement effective biosecurity procedures in domestic pig production $[5,21,36]$. In the study presented by Boklund et al. [41], the risk of ASF introduction was found to be associated with the herd size, visits by professionals working on farms and pigs foraging in ASF-affected areas. The situation in the neighboring Bulgaria, where pig backyard holdings are common, is quite similar [41]. In the first Bulgarian outbreak (Varna region, 2018), the source of infection was unknown $[8,44]$, but it was found that a contact with contaminated materials through human activities was the most likely route of virus introduction [15]. From June 2019 to January 2020, Bulgaria reported 225/49 ASF cases in wild boars and domestic pigs, respectively. Some of these cases were located close to the border with Greece. Soon after the first outbreak in Bulgaria, in February 2020, the first ASF cases were detected in the backyard domestic pig population in Greece [4]. In the above-mentioned affected countries, most ASF outbreaks appeared in the domestic pig sector, in backyard holdings. Due to low biosecurity, smallholder farms were considered particularly susceptible to ASF introduction and are of interest in programs for disease prevention and control $[21,22,44]$. The anthropogenic factor has been recognized to be the most relevant one in the current spreading ASF in Southeast Europe [15].

Like in other European countries, passive surveillance in domestic pigs and wild boars is a legal obligation in Serbia. From 2019, active surveillance in the domestic pig population has also been in place, including risk-based sampling and laboratory analysis. It is well known that surveillance activities, especially passive surveillance of wild boars and domestic pigs represent the most effective method of early ASF detection [32]. In Serbia, ASF control strategy is based on drastic measures with a strong impact on trade and economy, i.e., culling of all animals in affected premises and trade restrictions for live animals and products [34,35]. In order to reduce the 
socioeconomic impact, timely compensation for economic losses to animal owners is crucial. Current compensation policies in place include a $100 \%$ compensation. However, like in other European countries, the compensation for indirect losses of production (empty stable period) is not included.

From 2007, the epidemiological data from the European continent clearly indicate that wild boars represent the predominant host for ASF [21,24]. With the exception of two resolved point excursions of ASF, in the Czech Republic and Belgium, disease spread has so far been very difficult to control in the current European epidemic. Unfortunately, no European-wide harmonized monitoring scheme currently exists to gather information on hunting statistics. Each country collects hunting data using its own procedures, which hampers data comparison across Europe [24,32].

A high wild boar density is recognized as a risk factor contributing to the spread of ASF in the wild boar population [24,26]. A relative wild boar abundance in Serbia has increased in the recent decades. According to the number of hunted wild boars in relation to the expected wild boar numbers based on wild boar habitat, there is a higher density of wild boars than expected in Serbia. The reason for this may be related to climate changes, feeding, or the presence of crops that favor their proliferation $[15,28,32]$. According to EFSA [15], Serbia is hunting fewer wild boars than predicted by the suitable habitat. Consequently, the wild boar population is expected to grow in the next few years if this is not counteracted by a significant intervention. Also, a number of other factors may have a role in ASF spread, including the following: the presence of fenced hunting estates where wild boars are fed all year round, feeding wild boars outside the fenced hunting estates and baiting for hunting [15]. It should be additionally pointed out that the achieved epidemiological results indicate that when considering the locality of the hunting ground, the immediate environment should be considered, i.e., villages where extensive breeding of domestic pigs in the backyards and small holdings are dominant. At the same time, it is evident that domestic pigs are often kept as semi-free range or free-range in the forest, which currently represents the highest possible risk for spreading and transmission of the ASF virus between the two populations $[15,34,35]$.

Once ASF has been introduced in a previously ASF-free area, the disease can spread among wild boars through direct and indirect contact, for example through carcasses of wild boars that died of ASF and environmental contamination [11,20,41]. The carcass-mediated transmission pathway particularly seems to represent a mechanism of ASF spread in Europe nowadays [20,32]. In Serbia, the epidemic ASF in wild boars was mainly been detected in forest areas in the eastern parts of the country where there is the highest population density, closely connected to the neighboring Romania and Bulgaria. These areas are characterized by extensive breeding of domestic pigs and humans very often play a role in both direct and indirect spread of the virus between the two populations. This fact has just been established in the epizootiological research in this field [35]. Wild pigs in this region live exclusively in open hunting grounds. It is typical that in the period from the end of summer and the beginning of autumn, 
wild boars often leave their forest habitats in search of food and enter agricultural corn fields. In the fall, the activity of people in agricultural work during the corn harvest intensifies. At the same time, a direct contact of people, agricultural machines and equipment with the contaminated environment where wild boars lived is enabled. Namely, infected wild boars, carcasses of wild boars in the fields come into direct contact with agricultural machines and even the agricultural products themselves (corn), which the owners take to their households where domestic pigs are raised. It is a common practice that machine owners harvest corn of various crop owners, which directly increases the possibility of spreading the ASF virus to a larger number of households.

It is very difficult to control the movement of the wild boar population and their role in the direct and indirect spread of the ASF virus [2,28,32]. Recent events and the appearance of ASF outbreaks in Germany in the wild boar population confirm this. The first case of ASF in a wild boar in Germany was confirmed in 2020 at a distance of approximately $6 \mathrm{~km}$ from the Polish border [13]. Similar scenario was detected in Serbia close to the Bulgarian border in 2020. However, in Germany, like in some other European countries (Czech Republic, Belgium), the first control measures were focused on defining affected areas, intensive search for carcasses and fencing. As for the Serbian border area with Bulgaria, there is no fencing in areas at risk. It can be assumed that wild boars can regularly cross the border between the two countries. It was therefore not surprising that the first Serbian cases in wild boars were detected in 2020 in the districts close to the Serbian and Bulgarian border. A similar situation is on the border between Serbia and Romania. The infection pressure along the south and east part of the border between Bulgaria and Serbia resulted in ASF spreading in the wild boar population in this part of Serbia in 2020. Finally, in 2021 the continued infection pressure along the border with Romania resulted in the first cases of ASF in the wild boar population in the Northern-east part of the country. The new ASF introductions are very likely in the following period and there is an increased risk of spreading of infection in the western direction, in the densely populated region with domestic pigs in Serbia (Sremski and Macvanski District).

Unfortunately, due to the small number of reported wild boar carcasses, passive surveillance could not be considered as an efficient measure for early ASF detection in Serbia. According to Probst et al. [42] local scavengers are efficient in removing wild boar carcasses and may contribute to the reduction of the risk of virus persistence in the environment. In Serbia most widely the scavengers include jackals and foxes. This may be one of the potential reasons why very few carcasses of dead wild boars have been found.

Hunters have an important role in connecting domestic pigs and wild boars in Serbia as hunting is a widespread activity in villages in the whole country territory. It is very common that hunters are at the same time, keepers of domestic pigs in small holdings or backyards, which certainly facilitates the anthropogenic spread of the virus $[11,15,22,25]$. Therefore, it may be useful for different regions to identify risky 
human activities in the environment that are associated with the occurrence of ASF in wild boars. The movement of people is of potential relevance to ASF spread, because people have a potential to illegally (informally) move pork or pork products, including hunting trophies, wild boar meat and products from the affected areas [13,28,32].

\section{CONCLUSION}

In conclusion, the current epidemiological ASF situation in Serbia is closely related to the way the domestic pig production is organized in the country. Based on the analyzed data, we can conclude that all the important risk factors related to the spread of ASF in domestic pig populations in Serbia are directly and/or indirectly related to the smallholdings and backyard population. The anthropoid risky activities in these holdings are correlated with a low level or no biosecurity: home-slaughtering, swill feeding, natural mating and semi free and free-range domestic pigs keeping.

The analysis of the data on ASF outbreaks from the previous almost three-year period, showed that the disease is spreading more and more from south-east to north and north-west of the country. If the ASF control approach is not changed soon, and a general country-wide control strategy is developed, a professionally supported multidisciplinary problem-solving approach is implemented, Serbia will face with the spread of ASF to industrial farms with huge economic losses, and measures that have a strong negative socio-economic impact on the whole community. If all EFSA's criteria for Southeast Europe are taken into account, it is very clear that Serbia is a country where ASF will remain for a long time. Serbia fulfills all the criteria set by EFSA [15] in its risk analysis to be considered as a "very high risk" country.

\section{Aknowledgement}

This study was funded by Ministry of Education, Science and Technological development of Republic of Serbia by the Contract of implementation and financing of scientific research work of NIV-NS in 2021, Contract No: 451-03-9/202114/200031 from 05/02/2020.

\section{Authors' contributions}

VP carried out the data analysis and graphics, country map design, and drafted the manuscript. JM participated in the acquisition of wild boar population data and analysis. JPR participated in the data analysis and design of the review, helped VP to draft the manuscript. All authors read and approved the final manuscript.

\section{Declaration of conflicting interests}

The author(s) declared no potential conflicts of interest with respect to the research, authorship, and/or publication of this article. 


\section{REFERENCES}

1. Sánchez-Vizcaíno JM, Mur L, Gomez-Villamandos JC, Carrasco L: An update on the epidemiology and pathology of African swine fever. J Comp Pathol 2015, 152(1):9-21.

2. Gallardo MC, Reoyo AdlT, Fernández-Pinero J, Iglesias I, Muñoz MJ, Arias ML: African swine fever: a global view of the current challenge. Porcine Health Manag 2015, 1:21.

3. Alonso C, Borca M, Dixon L, Revilla Y, Rodriguez F, Escribano JM: ICTV virus taxonomy profile: Asfarviridae. J Gen Virol 2018, 99(5):613-614.

4. Brellou GD, Tassis PD, Apostolopoulou EP, Fortomaris PD, Leontides LS, Papadopoulos GA, Tzika ED: Report on the first african swine fever case in Greece. Vet Sci 2021, 8(8):163.

5. Dixon LK, Sun H, Roberts H: African swine fever. Antiviral Res 2019,165:34-41.

6. Ståhl K, Sternberg-Lewerin S, Blome S, Viltrop A, Penrith ML, Chenais E: Lack of evidence for long term carriers of African swine fever virus - a systematic review. Virus Res 2019, 272:197725.

7. Costard S, Wieland B, De Glanville W, Jori F, Rowlands R, Vosloo W, Roger F, Pfeiffer DU, Dixon LK: African swine fever: how can global spread be prevented? Philos Trans R Soc Lond B Biol Sci 2009, 364(1530):2683-2696.

8. Cwynar P, Stojkov J, Wlazlak K: African swine fever status in Europe. Viruses 2019, 11(4):310.

9. Gallardo C, Fernández-Pinero J, Arias M: African swine fever (ASF) diagnosis, an essential tool in the epidemiological investigation. Virus Res 2019, 271:197676.

10. Rowlands RJ, Michaud V, Heath L, Hutchings G, Oura C, Vosloo W, Dwarka R, Onashvili T, Albina E, Dixon LK: African swine fever virus isolate, Georgia, 2007. Emerg Infect Dis 2008, 14(12):1870-1874.

11. Chenais E, Depner K, Guberti V, Dietze K, Viltrop A, Ståhl K: Epidemiological considerations on African swine fever in Europe 2014-2018. Porcine Health Manag 2019, 5:6.

12. Gogin A, Gerasimov V, Malogolovkin A, Kolbasov D: African swine fever in the North Caucasus region and the Russian Federation in years 2007-2012. Virus Res 2013, 173(1):198203.

13. Sauter-Louis C, Forth JH, Probst C, Staubach C, Hlinak A, Rudovsky A, Holland D, Schlieben P, Göldner M, Schatz J, Bock S, Fischer M, Schulz K, Homeier-Bachmann T, Plagemann R, Klaaß U, Marquart R, Mettenleiter TC, Beer M, Conraths FJ, Blome S. Joining the club: First detection of African swine fever in wild boar in Germany. Transboundary Emerg Dis 2021, 68(4):1744-1752.

14. Dixon LK, Stahl K, Jori F, Vial L, Pfeiffer DU: African swine fever epidemiology and control. Annu Rev Anim Biosci 2020, 8:221-267.

15. Nielsen SS, Alvarez J, Bicout D, Calistri P, Depner K, Drewe JA, Garin-Bastuji B, Gonzales Rojas JL, Michel V, Miranda MA, Roberts H, Sihvonen L, Spoolder H, Ståhl K, Viltrop A, Winckler C, Boklund A, Bøtner A, Gonzales Rojas JL, More SJ, Thulke HH, Antoniou SE, Cortinas Abrahantes J, Dhollander S, Gogin A, Papanikolaou A, Gonzalez Villeta LC, Gortázar Schmidt C: Risk assessment of African swine fever in the south-eastern countries of Europe. EFSA J 2019, 17(11):e05861.

16. Zhou X, Li N, Luo Y, Liu Y, Miao F, Chen T, Zhang S, Cao P, Li X, Tian K, Qiu HJ, Hu R. Emergence of African swine fever in China, 2018. Transboundary Emerg Dis 2018, 65(6):1482-1484. 
17. You S, Liu T, Zhang M, Zhao X, Dong Y, Wu B, Wang Y, Li J, Wei X, Shi B: African swine fever outbreaks in China led to gross domestic product and economic losses. Nature Food 2021, 2(10):802-808.

18. Nurmoja I, Schulz K, Staubach C, Sauter-Louis C, Depner K, Conraths FJ, Viltrop A: Development of African swine fever epidemic among wild boar in Estonia-two different areas in the epidemiological focus. Sci Rep 2017, 7(1):12562.

19. Anon. OIE WAHIS 2021 Available from: https://wahis.oie.int/\#/dashboards/countryor-disease-dashboard, 01.11.2021.

20. Chenais E, Ståhl K, Guberti V, Depner K: Identification of wild boar-habitat epidemiologic cycle in African swine fever epizootic. Emerg Infect Dis 2018, 24(4):810-810.

21. Bellini S, Rutili D, Guberti V: Preventive measures aimed at minimizing the risk of African swine fever virus spread in pig farming systems. Acta Vet Scand 2016, 58(1):82.

22. Rolesu S, Mandas D, Loi F, Oggiano A, Dei Giudici S, Franzoni G, Guberti V, Cappai S. Rolesu S, Mandas D, Loi F, Oggiano A, Dei Giudici S, Franzoni G, Guberti V, Cappai S: African swine fever in smallholder Sardinian farms: last 10 years of network transmission reconstruction and analysis. Front Vet Sci 2021, 8:692448.

23. Gavier-Widén D, Gortázar C, Ståhl K, Neimanis AS, Rossi S, Hård av Segerstad C, Kuiken T: African swine fever in wild boar in Europe: a notable challenge. Vet Rec 2015, 176(8):199200.

24. Andraud M, Bougeard S, Chesnoiu T, Rose N: Spatiotemporal clustering and random forest models to identify risk factors of African swine fever outbreak in Romania in 2018-2019. Sci Rep 2021, 11(1):2098.

25. Chenais E, Boqvist S, Emanuelson U, von Brömssen C, Ouma E, Aliro T, Masembe C, Ståhl K, Sternberg-Lewerin S: Quantitative assessment of social and economic impact of African swine fever outbreaks in northern Uganda. Prev Vet Med 2017, 144:134-148.

26. Nurmoja I, Mõtus K, Kristian M, Niine T, Schulz K, Depner K, Viltrop A: Epidemiological analysis of the 2015-2017 African swine fever outbreaks in Estonia. Prev Vet Med 2018, 181:104556.

27. Carlson J, Fischer M, Zani L, Eschbaumer M, Fuchs W, Mettenleiter T, Beer M, Blome S: Stability of African swine fever virus in soil and options to mitigate the potential transmission risk. Pathogens 2020, 9(11):1-12.

28. Anon. Evaluation of possible mitigation measures to prevent introduction and spread of African swine fever virus through wild boar. EFSA J 2014, 12(3):3616.

29. Mur L, Atzeni M, Martínez-López B, Feliziani F, Rolesu S, Sanchez-Vizcaino JM: Thirtyfive-year presence of African swine fever in Sardinia: history, evolution and risk factors for disease maintenance. Transbound Emerg Dis 2016, 63(2):e165-77.

30. Beltrán-Alcrudo D, Kukielka EA, De Groot N, Dietze K, Sokhadze M, Martínez-López B: Descriptive and multivariate analysis of the pig sector in Georgia and its implications for disease transmission. PLoS ONE 2018, 13(8):e0202800.

31. Linden A, Licoppe A, Volpe R, Paternostre J, Lesenfants C, Cassart D, Garigliany M, Tignon M, van den Berg T, Desmecht D, Cay AB: Summer 2018: African swine fever virus hits north-western Europe. Transbound Emerg Dis 2019, 66(1):54-55.

32. Depner K, Gortazar C, Guberti V, Masiulis M, More S, Oḷševskis E, Thulke HH, Viltrop A, Woźniakowski G, Cortiñas Abrahantes J, Gogin A, Verdonck F, Dhollander S: Epidemiological analyses of African swine fever in the Baltic States and Poland. EFSA J 2017, 15(11):e05068. 
33. Mur L, Sánchez-Vizcaíno JM, Fernández-Carrión E, Jurado C, Rolesu S, Feliziani F, Laddomada A, Martínez-López B: Understanding African Swine Fever infection dynamics in Sardinia using a spatially explicit transmission model in domestic pig farms. Transbound Emerg Dis 2018, 65(1):123-134.

34. Milićević V, Kureljušić B, Maksimović Zorić J, Savić B, Stanojević S, Milakara E: First occurence of African swine fever in Serbia. Acta Vet-Beograd 2019, 69(4):443-449.

35. Nešković M, Ristić B, Došenović R, Grubač S, Petrović T, Prodanov-Radulović J, Polaček $\mathrm{V}$ : African swine fever outbreak investigation on large commercial pig farm in Serbia. Acta Vet-Beograd 2021, 71(2):219-229.

36. Bellini S, Casadei G, De Lorenzi G, Tamba M: A review of risk factors of African swine fever incursion in pig farming within the European Union scenario. Pathogens 2021, 10(1):84.

37. Anon. Adis: Outbreaks per disease-Total outbreaks from 2/1/2021 2021 Available from: https://ec.europa.eu/food/system/files/2021-11/ad_adns_outbreaks-per-disease_1.pdf, 23.10.2021.

38. Anon. Statistical Office of the Republic of Serbia-Numbers of pigs 2021 Available from: https:// data.stat.gov.rs / Home/Result/130202010203?languageCode=enUS\&displayMode $=$ table, 1.11.2021

39. De Lorenzi G, Borella L, Alborali GL, Prodanov-Radulović J, Štukelj M, Bellini S: African swine fever: a review of cleaning and disinfection procedures in commercial pig holdings. Res Vet Sci 2020, 132:262-267.

40. Bergmann H, Schulz K, Conraths FJ, Sauter-Louis C: A review of environmental risk factors for African Swine Fever in European wild boar. Animals (Basel) 2021, 11(9):2692.

41. Boklund A, Dhollander S, Chesnoiu Vasile T, Abrahantes JC, Bøtner A, Gogin A, Gonzalez Villeta LC, Gortázar C, More SJ, Papanikolaou A, Roberts H, Stegeman A, Ståhl K, Thulke $\mathrm{HH}$, Viltrop A, Van der Stede Y, Mortensen S: Risk factors for African swine fever incursion in Romanian domestic farms during 2019. Sci Rep 2020, 10(1):10215.

42. Probst C, Gethmann J, Amler S, Globig A, Knoll B, Conraths FJ: The potential role of scavengers in spreading African swine fever among wild boar. Sci Rep 2019, 9(1):11450.

43. Zani L, Masiulis M, Bušauskas P, Dietze K, Pridotkas G, Globig A, Blome S, Mettenleiter T, Depner K, Karvelienė B: African swine fever virus survival in buried wild boar carcasses. Transbound Emerg Dis 2020, 67(5):2086-2092.

44. Zani L, Dietze K, Dimova Z, Forth JH, Denev D, Depner K, Alexandrov T: African swine fever in a Bulgarian backyard farm-a case report. Vet Sci 2019, 6(4):94.

\title{
GLAVNI RIZICI I UTICAJ ŠIRENJA AFRIČKE KUGE SVINJA NA SVINJARSKU PROIZVODNJU U SRBIJI
}

\author{
Vladimir POLAČEK, Jovan MIRČETA, Jasna PRODANOV-RADULOVIĆ
}

Afrička kuga svinja (AKS) je virusno oboljenje domaćih i divljih svinja koja danas predstavlja jednu od glavnih pretnji svinjarskoj proizvodnji širom sveta. Usled nedostatka efikasne vakcine, kontrola bolesti se zasniva na biosigurnosnim merama u svi- 
njarskoj proizvodnji, brzoj dijagnostici bolesti i kompletnom uništavanju zaraženih zapata svinja. Shodno ovome, ovo oboljenje ima velike socio-ekonomske posledice ne samo na nacionalnom, već i na regionalnom nivou. Prvi slučaj AKS je detektovan 2019. godine u seoskom gazdinstvu u populaciji domaćih svinja u centralnom delu Srbije. Od tada, neprekidno se javljaju novi slučajevi AKS u populaciji domaćih i divljih svinja. U većini slučajeva pojave bolesti u populaciji domaćih svinja, AKS se dijagnostikuje u seoskim domaćinstvima. Primena biosigurnosnih mera nije regulisana zakonom, veterinarskim propisima kao obavezna za sprovođenje, već se navodi samo $\mathrm{u}$ formi preporuke. Sa druge strane, nije uvek jednostavno primeniti biosigurnosne mere koje su danas prepoznate kao nezaobilazne u kontroli bolesti i održivom stočarstvu, u postojećem starom tipu industrijskih farmi svinja.

Danas u 2021. godini, očigledno je da je ključni put širenja virusa AKS u populaciji domaćih svinja u direktnoj vezi sa ljudskim aktivnostima, koje su povezane sa svinjama ili proizvodima poreklom od svinja. Takođe, direktno i/ili indirektno aktivnosti ljudi su vrlo česta rizična veza između populacije domaćih i divljih svinja. Tradicija i kulturološki aspekti, zajedno sa činjenicom da političari ne prepoznaju AKS kao ozbiljan ekonomski problem predstavljaju važnu prepreku u kontroli ove bolesti. 